\title{
Umbilical Cord Mesenchymal Stem Cells for Inhibiting the Fibrosis and Autoimmune Development in HOCl-Induced Systemic Scleroderma Mouse Model
}

\author{
Xin Jin ${ }^{1,2}$, Jiali $\mathrm{Hou}^{1,2}$, Ke Zheng ${ }^{1,2}$, Dan Wei ${ }^{1,2}$, Ali Zhang ${ }^{3}$, \\ Siqi Wang ${ }^{2}$, Hua $\mathrm{Mei}^{2}$, Chuang $\mathrm{Li}^{2}$, Lamei Cheng ${ }^{1,2}$, Xuan Sun ${ }^{1,2}$ \\ ${ }^{I}$ Institute of Reproductive and Stem Cell Engineering, School of Basic Medical Sciences, Central South University, Changsha, China \\ ${ }^{2}$ National Engineering Research Center of Human Stem Cells, Changsha, China \\ ${ }^{3}$ Centre for Cardiovascular Sciences, Queen's Medical Research Institute, School of Clinical Sciences, University of Edinburgh, \\ Edinburgh, Scotland, UK
}

Background and Objectives: Systemic scleroderma (SSc) is a rare and serious connective tissue disease, an autoimmune disease, and a rare refractory disease. In this study, preventive effect of single systemic human umbilical cord mesenchymal stem cells (UC-MSCs) transfusion on SSc was preliminarily explored.

Methods and Results: SSc mouse model was established by daily intradermal injection of Hypochlorite (HOCl). SSc mice were treated by single transfusion of UC-MSCs at $0.625 \times 10^{5}, 2.5 \times 10^{5}$ and $1 \times 10^{6}$ respectively. At the 42 nd day of intradermal injection of $\mathrm{HOCl}$, the symptoms showed up by skin and alveolar wall thickening, lymphocytic infiltration, increased collagen in skin/lung, and the increased proportion of $\mathrm{CD}^{+} \mathrm{CD}^{+}{ }^{+} \mathrm{CD} 25^{+} \mathrm{FoxP}^{+}$cells (a Treg subset) in spleen. After UC-MSCs transfusion, the degree of skin thickening, alveolar wall thickening and lymphocyte infiltration were decreased, the collagen sedimentation in skin/lung was decreased, and the proportion of $\mathrm{CD} 3^{+} \mathrm{CD} 4^{+} \mathrm{CD} 25^{+}$ $\mathrm{FoxP}^{+}$cells was decreased.

Conclusions: UC-MSC can achieve a preventive effect in SSc mice by fibrosis attenuation and immunoregulation.

Keywords: Mesenchymal stem cells, Immunoregulation, Regulatory T cell, Systemic scleroderma

Received: January 1, 2020, Revised: May 2, 2020,

Accepted: May 14, 2020, Published online: June 30, 2021

Correspondence to Xuan Sun

Institute of Reproductive and Stem Cell Engineering, School of Basic Medical Sciences, Central South University, 8 Luyun Road, Changsha 410205, China

Tel: +86-731-88395675, Fax: +86-731-82650401

E-mail: almasun97184@hotmail.com

(c) This is an open-access article distributed under the terms of the Creative Commons Attribution Non-Commercial License (http://creativecommons.org/ licenses/by-nc/4.0/), which permits unrestricted non-commercial use, distribution, and reproduction in any medium, provided the original work is properly cited.

Copyright (c) 2021 by the Korean Society for Stem Cell Research

\section{Introduction}

Mesenchymal stem cell (MSC) regulates the activation, differentiation, maturation, inflammatory factor secretion and migration of various lymphocytes (1). MSC also has the potential to influence the differentiation, maturation and immune function of antigen-presenting cells (APCs) to transform APCs into suppressive or tolerant form (2). Due to the low immunogenicity and excellent immunoregulation effect, MSC has been widely applied for various autoimmune diseases, including: Systemic scleroderma (SSc), systemic lupus erythematosus, psoriasis, Crohn's disease and graft verus host disease (GVHD) (3-6).

Systemic scleroderma (SSc) is a rare autoimmune disease, which mainly influences the middle-aged patients, 
its morbidity rate varies in different countries at $100 \sim$ $300 / 1,000,000$. With the main characteristics of vascular endothelial impairment and diffuse fibrosis, SSc mainly affects the skin and lung tissues, as well as the function of the heart and digestive tract (7). The earliest and most common symptoms of SSc are skin sclerosis and Raynaud's phenomenon. Up until now, no cure has been found and only the conservative treatment were used to ease the pain and maintain the organ functions (8). MSCs transfusion is regarded as a very prospective method for SSc treatment.

In 2008, the first article on the SSc treatment with MSCs was published by German Christopeit et al. (9): in the female SSc patient of 41 years old, at 6 months after the intravenous injection of MSCs derived from related donor bone marrow, the ulcer at multiple sites was significantly improved. In 2011, 5 SSc patients were reported by German Keyszer et al. (10): after the transplantation of MSCs derived from related donor bone marrow, the indices such as modified Rodan skin score (MRSS), pulmonary function and ulcers were obviously improved. In 2012, 5 SSc patients were reported by Akiyama et al. (11): after the transplantation of umbilical cord mesenchymal stem cells (UC-MSCs), health assessment questionnaire disability index (HAQ-DI) was improved. In 2015, 12 female SSc patients were reported by French Granel et al. (12): at 6 months after the hypodermic injection of autogenous adipose MSCs in finger, hand function and quality of life were obviously improved. Many studies have shown that MSC has the effects on immune remodeling, anti-fibrosis, antioxidation, promoting angiogenesis and so on.

Mouse bone marrow-derived MSC (BM-MSC) and adipose-derived MSC (AD-MSC) are the popular choices to treat SSc animal models. However, compared to BM-MSC and AD-MSC, UC-MSC is younger, less affected by external environment, lower immunogenicity and stronger immunomodulatory function, easier to carry out quality control and industrialization (13). Therefore, we chose UC-MSCs to treat SSc, and preliminarily explored the related mechanism.

\section{Materials and Methods}

\section{Ethics statement}

This study protocol was approved by the Ethics Committee of School of basic Medicine, Central South University under the number 2020KT-20. This study was conducted in accordance with the guidelines of Helsinki Declaration.

\section{MSC culturing}

Human UC-MSCs were provided by Hunan Provincial Bank of Stem Cells, National Engineering Research Center of Human Stem Cells. Its quality conformed to the use standard for quality control, delivery and clinical trial in National Engineering Research Center of Human Stem Cells. The UC-MSCs was cultured to the fourth generation for experiment.

\section{T cell proliferation test}

With the informed consent of healthy volunteers, peripheral blood was collected. Peripheral blood mononuclear cells (PBMCs) were obtained through the separation with human peripheral blood lymphocyte separating solution. MSCs treated with Mitomycin C (Sigma, USA) were inoculated in 24-well plate. After the overnight culture, PBMCs were inoculated by $1 \times 10^{6}$ cells/well, which was then cultured in RPMI-1640 (Hyclone, USA) containing 10\% FBS. Phytohemagglutinin (PHA, $10 \mu \mathrm{g} / \mathrm{ml}$ ) (Sigma, USA) was added to stimulate PBMCs. PBMCs were treated by CFDA-SE Cell Proliferation Assay Tracking Kit. Proliferation conditions of T cells were determined by flow cytometry.

\section{Cytokine measurements}

PBMCs from healthy volunteers were co-cultured with MSCs treated by Mitomycin C in 24-well plate. Typical cell factors related to inflammation in the supernatant were measured by Luminex technique, including: pro-inflammatory factors and inflammation-inhibitory factors.

\section{Experimental design and animals}

8-weeks-old and pathogen-free female $\mathrm{BALB} / \mathrm{c}$ mice (bought from Hunan SJA Laboratory Animal Co., Ltd.) were raised and cared. All animal experiments were conducted in agreement with the Guide for the Care and Use of Laboratory Animals. During the study period, the skin thickness was measured weekly. As previously described, $\mathrm{HOCl}$ was prepared temporarily just before the use (14).

A total of $400 \mu 1 \mathrm{HOCl}$ was injected intradermally in two sites daily into the back of mice, continuously for 42 days (6 weeks). In blank control group, phosphate buffer solution (PBS) was injected daily under same conditions. In UC-MSC group, at Day 0 of modeling, $100 \mu 1$ UC-MSCs was transfused in tail vein at the cell doses of $0.625 \times 10^{5}$ cells (low dose group), $2.5 \times 10^{5}$ cells (medium dose group) and $1 \times 10^{6}$ cells (high dose group) respectively (Fig. 1). At Day 42, the mice were sacrificed through the peritoneal injection of excessive anesthetics, and skin, lung and spleen tissues of mice were taken. 


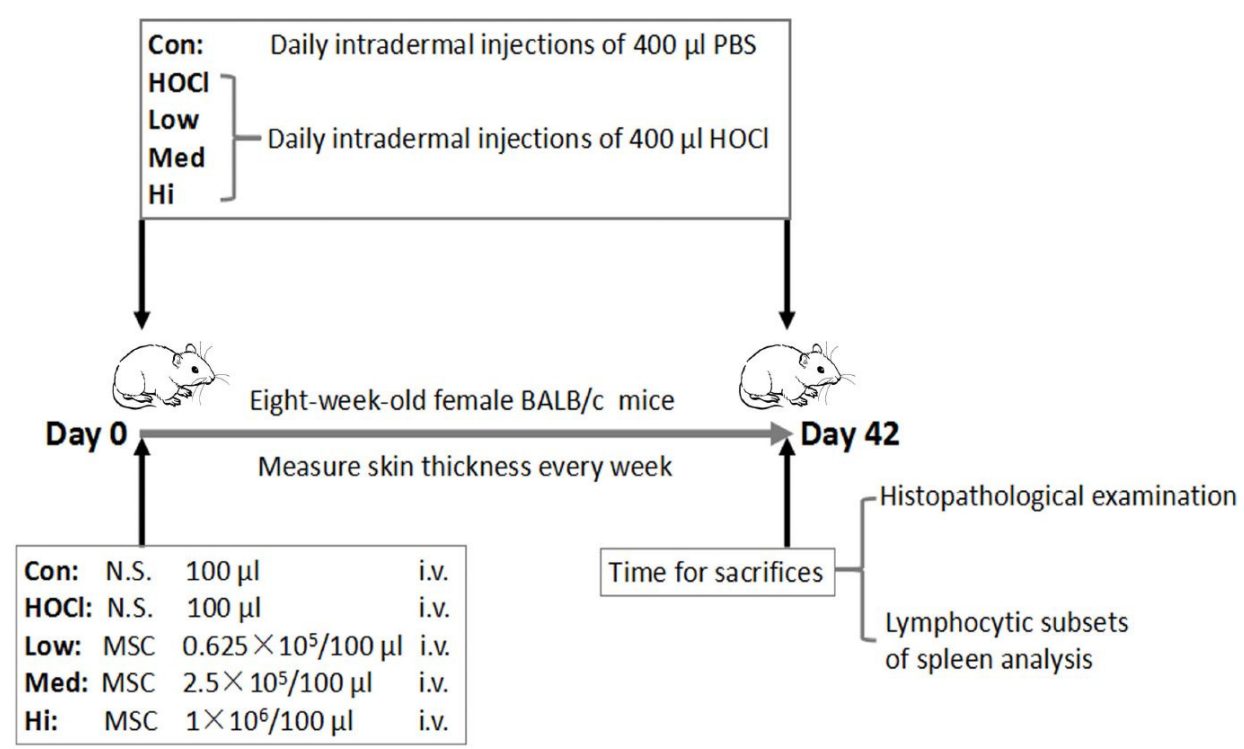

Fig. 1. Protocol of animal experiment. In the induced SSc mouse model, $\mathrm{HOCl}(400 \mu \mathrm{l} / \mathrm{d})$ was injected intradermally for 42 days in 8-weeks-old female BALB/c mice. In control group, PBS was injected intradermally at equivalent dose. In UC-MSCs treatment groups, at Day 0 of modeling, $100 \mu$ l UC-MSCs were infused once in tail vein of mice at the doses of $0.625 \times 10^{5}$ cells (low dose group), $2.5 \times 10^{5}$ cells (medium dose group) and $1 \times 10^{6}$ cells (high dose group). The skin thickness of mice was measured weekly in each group. At Day 42 (i.e. Week 6), the mice were sacrificed, and specimens were collected for histopathological examination and analysis of lymphocyte subsets in splenocytes.

\section{Histopathological analysis}

HE staining was made on paraffin sections of skin and lung tissues. Dermis thickness was measured by randomly selecting 30 points in the sections of skin and lung tissues of each mouse. Through Masson's Trichrome Stain Kit (Solarbio, China), Masson Trichrome staining was made to stain the collagen in the sections of skin and lung tissues. Through the immunofluorescence staining, TGF$\beta 1^{+}$cells, $\alpha-\mathrm{SMA}^{+}$cells and $\mathrm{F} 4 / 80^{+}$cells were labeled in the sections of skin and lung tissues. For the immunofluorescence staining, the following primary antibodies were used: rabbit anti-mouse TGF beta 1 polyclonal antibody, goat anti-mouse alpha smooth muscle actin polyclonal antibody and rabbit anti-mouse F4/80 polyclonal antibody (Abcam, UK).

\section{Flow cytometry}

In vitro test, proliferation conditions of $\mathrm{T}$ cells and immune cell subsets of PBMCs were determined by flow cytometry. The following antibodies were used: Mouse Anti-Human CD3-FITC, Mouse Anti-Human CD4-PE, Mouse Anti-Human CD8-APC, Mouse Anti-Human CD25$\mathrm{APC}$ and Mouse Anti-Human CD127-PE/Cy7 (Biolegend, USA).

In vivo test, change of immune cell subsets in the splenocytes of mice was determined by flow cytometry. The following antibodies were adopted: Rat Anti-Mouse CD3FITC, Rat Anti-Mouse CD4-PE, Rat Anti-Mouse CD8aAPC, Rat Anti-Mouse CD19-PE and Mouse Regulatory T Cell Staining Kit (Invitrogen, USA).

\section{Statistical analysis}

Quantitative data were expressed with mean \pm standard deviation (SD). Gaussian distribution of measurement data were determined by Shapiro-Wilk normality test, and then the data were compared by Student's t test. Data included in more than two groups were analyzed by one-way ANOVA method. The data were statistically analyzed by GraphPad Prism 6 software. $p<0.05$ indicated that the difference was significant.

\section{Results}

\section{In vitro UC-MSCs regulated T cell proliferation and the proportion of the lymphocytes subsets}

According to the literatures and preliminary results of this study, MSCs have the ability to inhibit the proliferation of active PBMCs (data not shown). In this study, compared to the PHA-PBMC positive control group, the proliferation of T cells was inhibited by UC-MSCs. The inhibition effect is positively linked to the concentration of PBMCs (Fig. 2A and Fig. 3A).

With PHA stimulation, the proportion of $\mathrm{CD}^{+} \mathrm{T}$ cells in PBMCs was decreased; the proportion of $\mathrm{CD}^{+} \mathrm{T}$ cells was decreased; the proportion of $\mathrm{CD} 8^{+} \mathrm{T}$ cells was increased; the proportion of $\mathrm{CD}^{+} \mathrm{CD} 4^{+} \mathrm{CD} 25^{+} \mathrm{CD} 127^{-}$ Treg cells in $\mathrm{CD}^{+}{ }^{+} \mathrm{T}$ cells was decreased; actual count of Treg cells was decreased by nearly $60 \%$; since the proportion of $\mathrm{CD}^{+}$cells was significantly decreased, the proportion of Treg cells in $\mathrm{CD}_{3}{ }^{+} \mathrm{CD}^{+}{ }^{+} \mathrm{T}$ cells increased on the contrary. Different outcomes when we co-cultured them with MSCs without PHA stimulation, the proportion of $\mathrm{CD}^{+} \mathrm{T}$ cells in human PBMCs was decreased; the pro- 

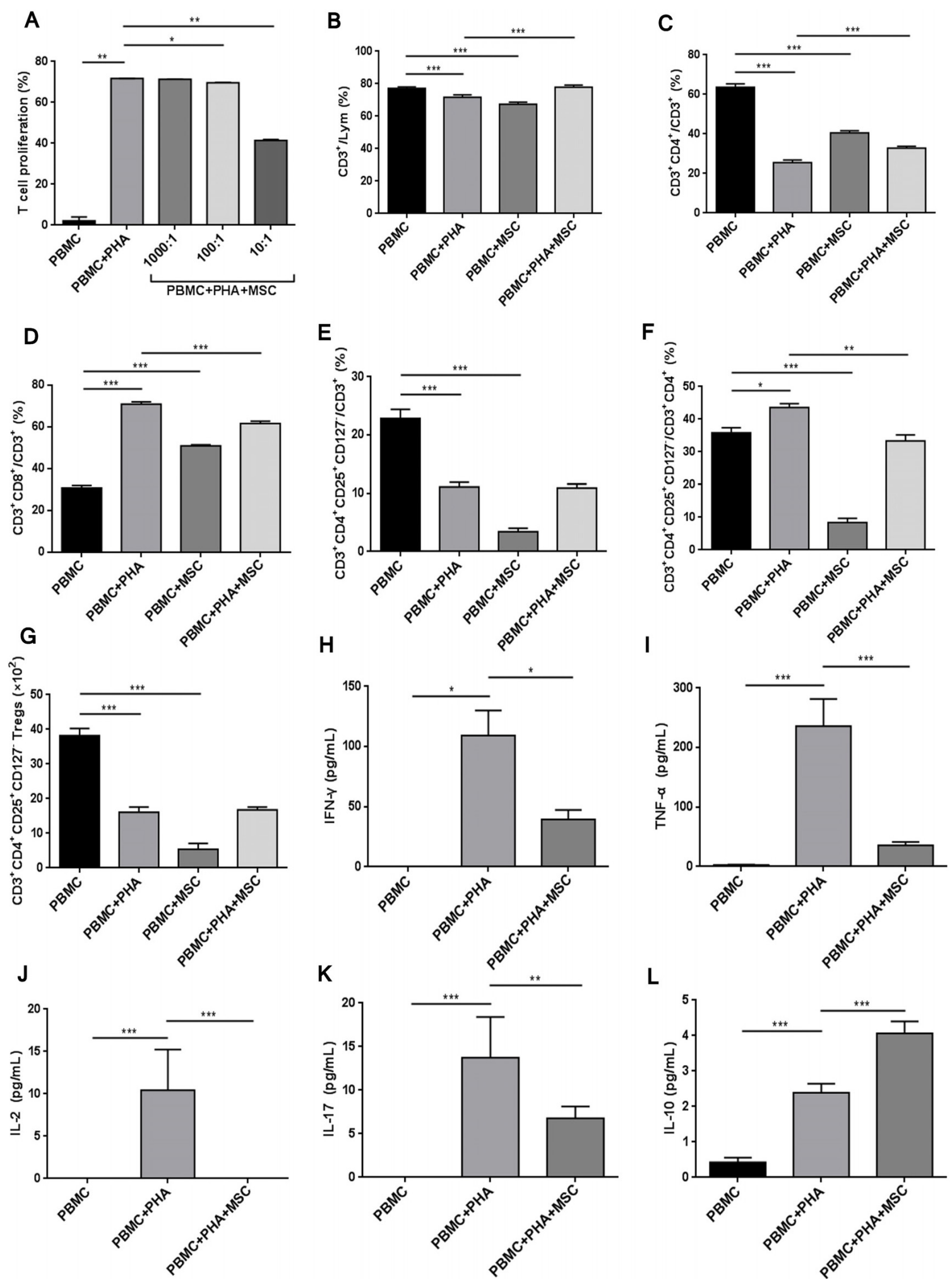

Fig. 2. UC-MSCs regulated the proportion of lymphocyte subsets. (A) UC-MSCs inhibited the proliferation of T cells (PBMCs/MSCs ratio was $1,000: 1,100: 1$ and $10: 1$ respectively). (B) The proportion of $\mathrm{CD}^{+}{ }^{+}$T cells in total lymphocytes. (C) The proportion of $\mathrm{CD} 3^{+} \mathrm{CD} 4^{+}$ helper $\mathrm{T}$ cells in $\mathrm{CD}^{+} \mathrm{T}$ cells. (D) The proportion of $\mathrm{CD} 3^{+} \mathrm{CD} 8^{+}$cytotoxic $\mathrm{T}$ cells in $\mathrm{CD} 3^{+} \mathrm{T}$ cells. (E) The proportion of $\mathrm{CD} 3^{+} \mathrm{CD} 4^{+} \mathrm{CD} 25^{+}$ $\mathrm{CD} 127^{-}$Treg cells in $\mathrm{CD}^{+}{ }^{+}$cells. (F) The proportion of Treg cells in $\mathrm{CD} 3^{+} \mathrm{CD} 4^{+} \mathrm{T}$ cells. (G) The count of Treg cells. The concentration of cell factors in the supernatant of culture medium: (H) IFN- $\gamma$, (I) TNF- $\alpha$, (J) IL-2, (K) IL-17, (L) IL-10. ${ }^{*} \mathrm{p}<0.05,{ }^{* *} \mathrm{p}<0.01$ and $* * * \mathrm{p}$ $<0.001$. 

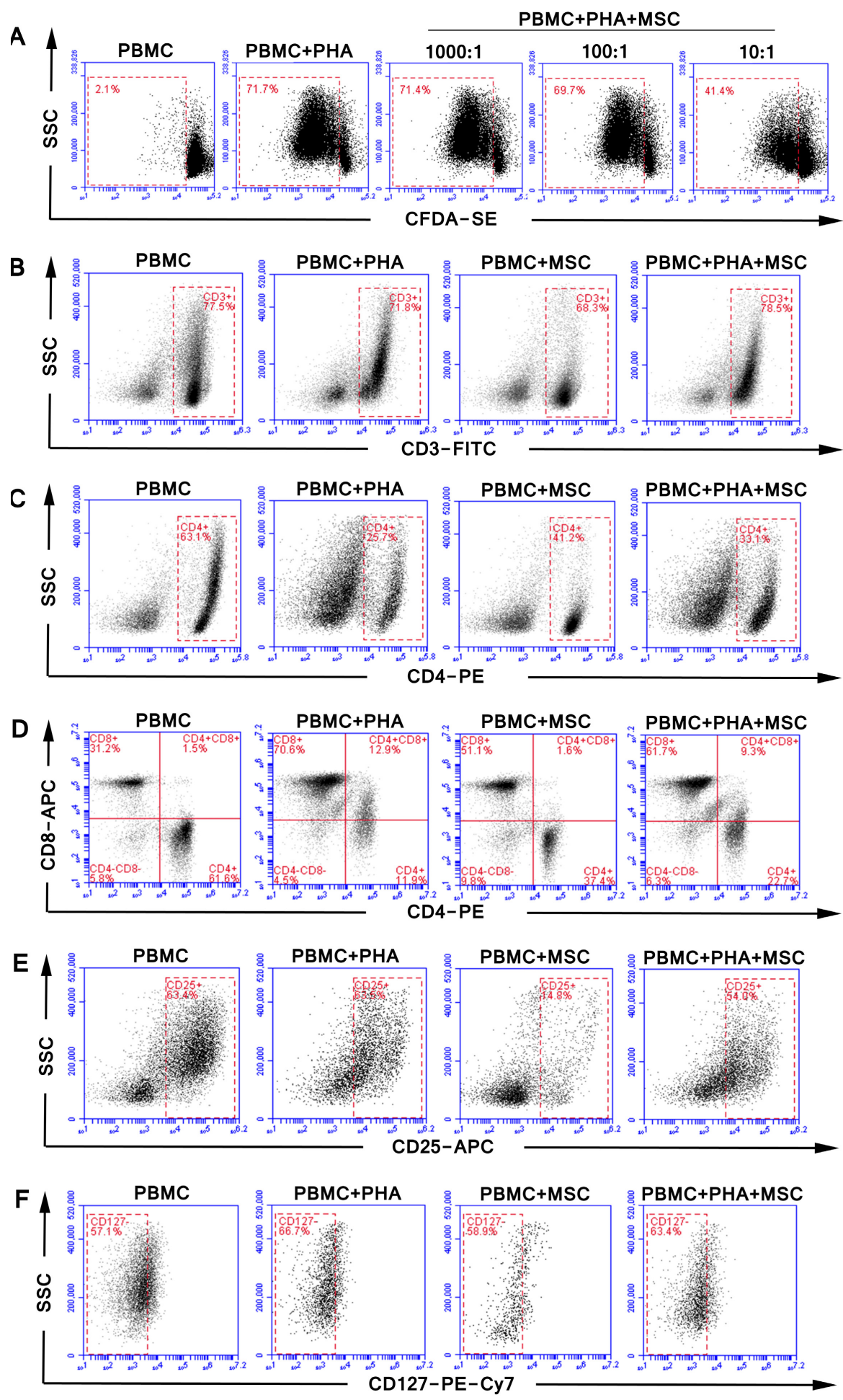

Fig. 3. The representative FACS cytograms of vitro experiment. The effect of (A) different ratios of UCMSCs (PBMCs/MSCs ratio was 1,000 and 1 and $10: 1$ respectively) on $T$ cell proliferation, and the effect of UC-MSCs on the proportion of (B) $\mathrm{CD}^{+}{ }^{+}$cells $(\mathrm{C}) \mathrm{CD}^{+}{ }^{+} \mathrm{CD} 4^{+}$helper $\mathrm{T}$ cells, (D) $\mathrm{CD}^{+}{ }^{+} \mathrm{CD} 8{ }^{+}$cytotoxic $\mathrm{T}$ cells, (E) $\mathrm{CD}^{+}{ }^{+} \mathrm{CD} 44^{+} \mathrm{CD} 25^{+}$Treg cells, (F) $\mathrm{CD}^{+} \mathrm{CD} 4^{+} \mathrm{CD} 25^{+} \mathrm{CD} 127^{-}$ Treg cells with or without PHA stimulation.

portion of $\mathrm{CD} 4^{+} \mathrm{T}$ cells was decreased; the proportion of $\mathrm{CD} 8^{+} \mathrm{T}$ cells was increased; the proportion of Treg cells in $\mathrm{CD}^{+}{ }^{+} \mathrm{T}$ cells and $\mathrm{CD} 3{ }^{+} \mathrm{CD} 4{ }^{+} \mathrm{T}$ cells was decreased; actual count of Treg cells was obviously decreased; change trend of MSCs for influence on PBMC cell subsets was similar to that for PHA influence. These data indicated MSCs were pro-inflammatory under non-inflammatory conditions.

Under inflammatory environment, MSCs were inflammation-inhibitory. When MSCs were stimulated by 
PHA, the proportion of $\mathrm{CD}^{+}$T cells in PBMC lymphocytes was increased; the proportion of $\mathrm{CD} 3{ }^{+} \mathrm{CD} 4^{+} \mathrm{T}$ cells in $\mathrm{CD}^{+} \mathrm{T}$ cells was increased; the proportion of $\mathrm{CD} 3^{+}$ $\mathrm{CD}^{+} \mathrm{T}$ cells in $\mathrm{CD}^{+} \mathrm{T}$ cells was decreased; the proportion of Treg cells in $\mathrm{CD}^{+} \mathrm{CD}^{+} \mathrm{T}$ cells was significantly decreased; but the proportion of Treg cells in $\mathrm{CD}^{+} \mathrm{T}$ cells or its actual count was not significantly changed in this process. Therefore, under inflammatory environment, MSCs rescued PHA's inhibitory effect on Treg cells (Fig. 2B G and Fig. 3B F).

\section{Influence of MSCs on lymphocyte secretion of cell factors}

Compared to the PBMC+PHA group in the supernatant of culture medium collected after the co-culturing of MSCs and PBMCs, the concentration of pro-inflammatory IFN- $\gamma$, TNF- $\alpha$, IL-2 and IL-17 determined by Luminex technique was obviously decreased (Fig. $2 \mathrm{H}$ $\sim \mathrm{K})$. The concentration of inflammation-inhibitory factor IL-10 was nearly doubled in the MSC group (Fig. 2L), verifying the inflammation-inhibitory role of MSCs.

\section{Skin thickening and alveolar wall thickening were alleviated after the UC-MSCs treatment in HOCl-SSc mice}

At Day 0, UC-MSCs at different doses were systematically transfused first by single injection. The skin thickness data of mice during the 42-day modeling period were summarized (Fig. 1 and Fig. 4A), showing that UC-MSCs had an effect of preventive treatment in HOCl-SSc mouse model. As shown by the weekly relative change ratio of skin thickness during 42-day modeling period, the skin thickness in control group was slightly decreased; the skin thickness in $\mathrm{HOCl}$ group was significantly increased; and the skin thickness was significantly inhibited in cytotherapy groups of three doses (Fig. 4B). At Day 42, skin thickness in UC-MSC groups of three doses was significantly decreased than that in $\mathrm{HOCl}$ group (Fig. 4C). In the $\mathrm{HOCl}$ group, skin thickness was increased; in UC-MSC groups of low, medium and high dose, the skin thickness was not changed by $6.67 \%(1 / 15), 28.57 \%$ (4/14) and $40 \%$ (6/15) respectively. Higher the UC-MSCs concentration, the less increase in skin thickness (Fig. 4D). As also further verified by the change in dermis thickness, UC-MSCs were effective at a dose-dependent relation in SSc mice (Fig. 4E).

As shown by HE staining on sections of mice skin, after the UC-MSCs treatment, the extracellular matrix (ECM) sedimentation and the cell infiltration in skin were decreased, and the skin thickness was decreased more ob- viously with the increase in dose of UC-MSCs (Fig. 4F). As shown by $\mathrm{HE}$ staining on sections of lung tissues, the fibrosis injury of mice lung in UC-MSC groups was lighter than that in $\mathrm{HOCl}$ group. With the increase in dose of MSCs, the structure of alveolar wall was more approximated to normal state, and fewer cells were infiltrated (Fig. 4G).

\section{Collagen sedimentation in skin and lung tissues of SSc mice was decreased, fibrosis marker level was down-regulated, and macrophages were decreased after the UC-MSCs treatment}

Larger Masson Trichrome staining-stained (in blue and green) area in the HOCl-induced disease model indicated an increase of the collagen sedimentation. After the UC-MSCs treatment, the blue staining area in mice skin was obviously decreased, indicating that the collagen content was lower (Fig. 5A). As shown by the collagen sediment situation in the lung tissues, the MSCs transfusion showed the same effect in the skin (Fig. 5B). Quantification of the collagen-staining was accomplished by Image $\mathrm{J}$ (Fig. 5C and 5D), the change of collagen content in skin and lung tissues of mice was relevant to the dose of UC-MSCs in UC-MSC groups: the larger dose of cells, the lower content and closer to normal level of collagen in tissues.

As shown by immunohistochemistry results, the cells with positive results of TGF- $\beta 1, \alpha$-SMA and F4/80 in mice skin were significantly decreased in UC-MSC groups compare to $\mathrm{HOCl}$ group (Fig. 6A). The influence of MSCs showed dose dependence effect by quantitating the TGF$\beta 1$-positve cells and $\alpha$-SMA-positve cells; medium dose group and high dose group were not significantly different compare to control group; and their expression level was lower in high dose group. Therefore, after UC-MSCs treatment, the degree of fibrosis in the skin of SSc mice, macrophage infiltration and secretion of inflammatory factor were all decreased (Fig. 6B D).

In short, as shown by histological analysis, a significant effect of dose dependence effect was achieved in SSc mice after UC-MSCs treatment, such as resistance against fibrosis, collagen sedimentation and macrophage infiltration. At the dose of $1 \times 10^{6}$ cells, the therapeutic effect of MSC was the most significant, i.e. equivalent to about $3.88 \times 10^{8}$ cells for once injection in a person of $70 \mathrm{~kg}$ (based on the ratio of equivalent dose between human being and animals converted according to the body surface area). 


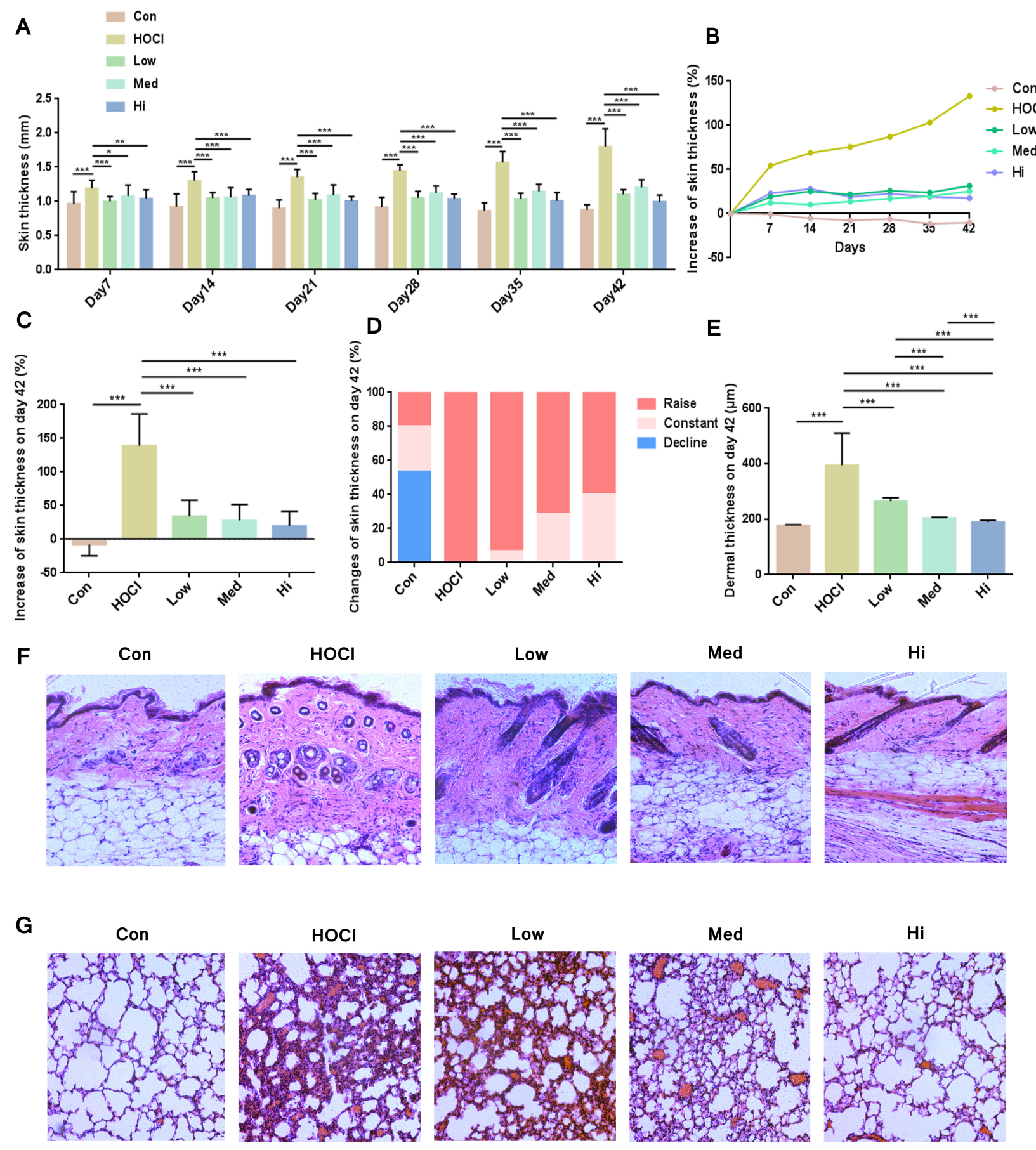

Fig. 4. Therapeutic effect of UC-MSCs in SSc mouse model. (A) The skin thickness of mice $(n=15)$. (B) Compared to the skin thickness of mice before modeling, the weekly increase percentage of skin thickness $(n=15)$. (C) The increase percentage of skin thickness at Day $42(n=15)$. (D) The proportion of mice with an increase, no change or decrease of skin thickness at Day $42(n=15)$. (E) Dermis thickness of skin sections; HE staining on the representative sections of (F) skin and (G) lung obtained at Day 42 (amplification ratio 200 $\times$ ). ${ }^{*} p<0.05$, $* * \mathrm{p}<0.01$ and $* * * \mathrm{p}<0.001$.

\section{Changes of immune cell subsets in the spleen of SSc mice}

Compared to the control group, the proportion of $\mathrm{CD}^{+}$ $\mathrm{T}$ cells and $\mathrm{CD} 19^{+} \mathrm{B}$ cells was not obviously changed in the $\mathrm{HOCl}$ group; and the proportion of $\mathrm{CD}^{+} \mathrm{CD}^{+}$helper $\mathrm{T}$ cells in $\mathrm{CD}^{+} \mathrm{T}$ cells was significantly decreased; the proportion of $\mathrm{CD}^{+}{ }^{+} \mathrm{CD}^{+}$killer $\mathrm{T}$ cells in $\mathrm{CD}^{+}{ }^{+} \mathrm{T}$ cells was significantly increased; and the count of $\mathrm{CD}^{+} \mathrm{CD}^{+}$ 
A

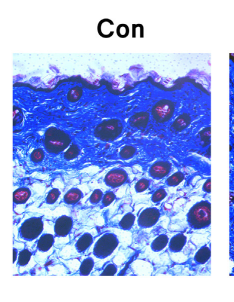

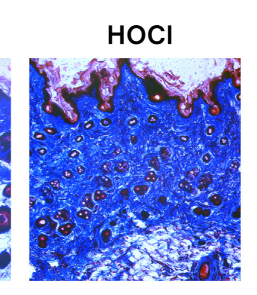
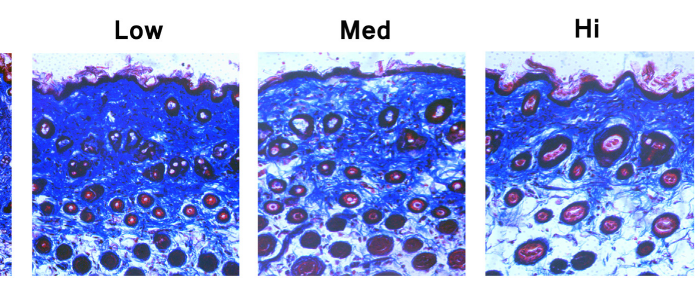

B
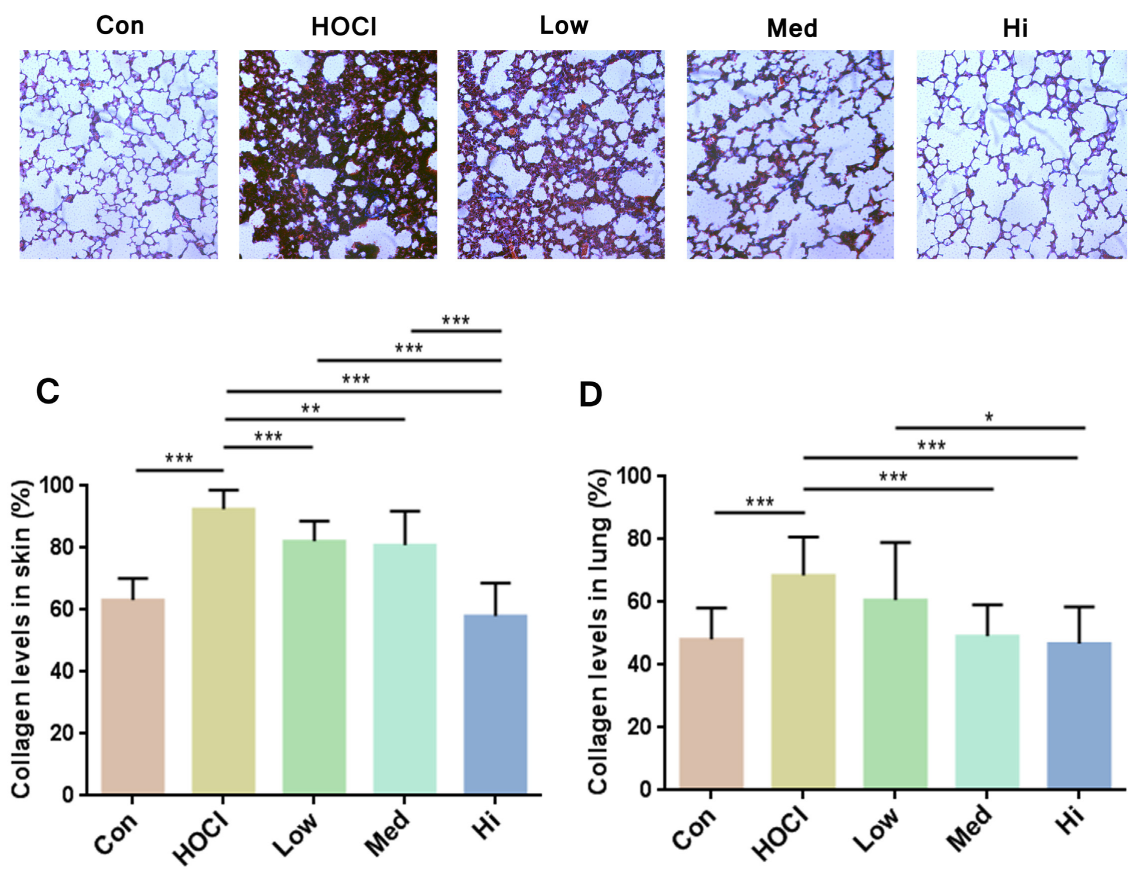

D

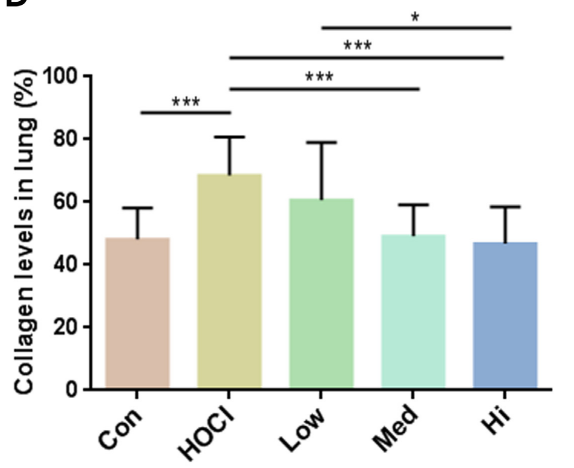

Fig. 5. Staining of collagen in the sections of skin and lung tissues. Representative sections of (A) skin and (B) lung obtained at Day 42 (amplification ratio $200 \times$ ), sections were stained with Masson Trichrome staining. Analysis of Masson Trichrome staining on (C) skin and (D) lung sections by Image J software and calculation of collagen volume fraction $(\mathrm{n}=15) . \quad * \mathrm{p}<0.05, \quad * * \mathrm{p}$ $<0.01$ and $* * * \mathrm{p}<0.001$.
$\mathrm{CD} 25^{+} \mathrm{FoxP}^{+}$Treg cells and its proportion in $\mathrm{CD}^{+}{ }^{+} \mathrm{CD} 4{ }^{+}$ $\mathrm{T}$ cells was significantly increased.

In the MSC groups of three different doses, the proportions of $\mathrm{T}$ cells and $\mathrm{B}$ cells in the lymphocytes of SSc mice were not obviously changed over that in the $\mathrm{HOCl}$ group. Compared to the $\mathrm{HOCl}$ group, the proportion of $\mathrm{CD}^{+}$helper $\mathrm{T}$ cells was increased in UC-MSC groups, and the proportion and the count of $\mathrm{CD} 8^{+}$killer $\mathrm{T}$ cells and Treg cells were decreased, which was the most significantly different in high dose group. The changed proportion of the immune cells confirmed the immunoregulatory role of the MSCs (Fig. $6 \mathrm{E} \sim \mathrm{J}$ and Fig. 7).

\section{Discussion}

SSc patients are mainly treated by anti-inflammation, immunoregulation, treatment of vascular lesion and anti-fibrosis, which has a long treatment course and causes obvious adverse drug reactions (15-17). With various strong effects such as self-duplication, immunoregulation, vascularization promotion and secretion, MSC becomes the hot spot of treatment for autoimmune disease. Compared to MSCs from healthy people, proliferation ability, metabolism activity, migration ability and invasion ability are lower in MSCs from SSc patients (18, 19). MSCs extracted from umbilical cord of fetus tissues are more primordial, which possess a stronger proliferation ability, lower immunogenicity and stronger immunoregulation ability; therefore, UC-MSC is a better drug candidate for autoimmune disease. As verified in our study, human UC-MSC possessed a strong effect of preventive treatment for SSc mice. Different from murine BM-MSC, UC-MSC could significantly decrease the thickness of the skin on the seventh day of treatment. The efficacy of human UC-MSC was at a relation of dose dependence. The efficacy of low, middle and high level was achieved by the cell doses of $0.625 \times 10^{5}, 2.5 \times 10^{5}$ and $1 \times 10^{6}$ respectively for improving the skin thickness, pulmonary fibrosis and collagen sedimentation, reducing the expression level of fibrosis proteins (such as TGF- $\beta 1$ and $\alpha$-SMA), decreasing the macrophage aggregation and regulating the immune cells. During the whole 42-day study observation pe- 

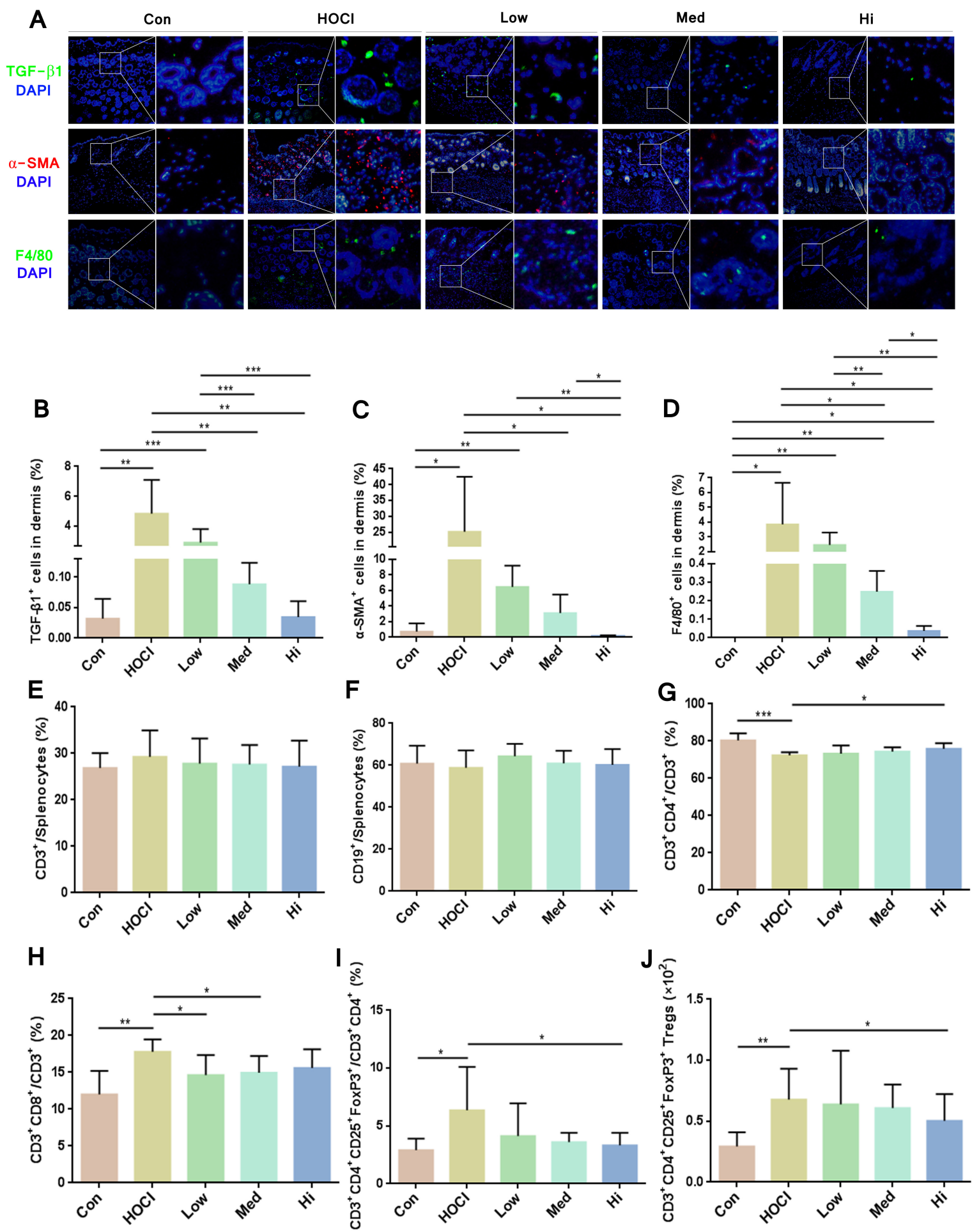

Fig. 6. The immunoregulatory effect of UC-MSCs in vivo. (A) Immunofluorescence staining on representative sections of skin obtained at Day $42\left(\mathrm{TGF}-\beta 1^{+}\right.$: green, $\alpha-\mathrm{SMA}^{+}$: red, $\mathrm{F} 4 / 80^{+}$: green, DAPI: blue), amplification ratio $100 \times$ for left diagram, amplification ratio $400 \times$ for right diagram of each group; Analysis of immunofluorescence staining on skin sections by Image J software $(n=6)$ and calculation of fluorescent area percentage of (B) TGF- $\beta 1^{+}$, (C) $\alpha-\mathrm{SMA}^{+}$and (D) $\mathrm{F} 4 / 80^{+}$in the skin. The proportion of (E) $\mathrm{CD}^{+}{ }^{+}$cells and (F) $\mathrm{CD}_{19}{ }^{+} \mathrm{B}$ cells in the splenocytes; the proportion of $(\mathrm{G}) \mathrm{CD}^{+}{ }^{+} \mathrm{CD} 4^{+}$helper $\mathrm{T}$ cells and $(\mathrm{H}) \mathrm{CD}^{+}{ }^{+} \mathrm{CD} 8^{+}$killer $\mathrm{T}$ cells in $\mathrm{CD} 3^{+} \mathrm{T}$ cells; the proportion of (I) $\mathrm{CD} 3{ }^{+} \mathrm{CD} 4{ }^{+} \mathrm{CD} 25^{+} \mathrm{FoxP}^{+}$Treg cells in $\mathrm{CD} 3{ }^{+} \mathrm{CD} 4{ }^{+} \mathrm{T}$ cells; and the count of (J) Treg cells. ${ }^{*} \mathrm{p}<0.05,{ }^{* *} \mathrm{p}<0.01$ and $* * * \mathrm{p}<0.001$. 
A

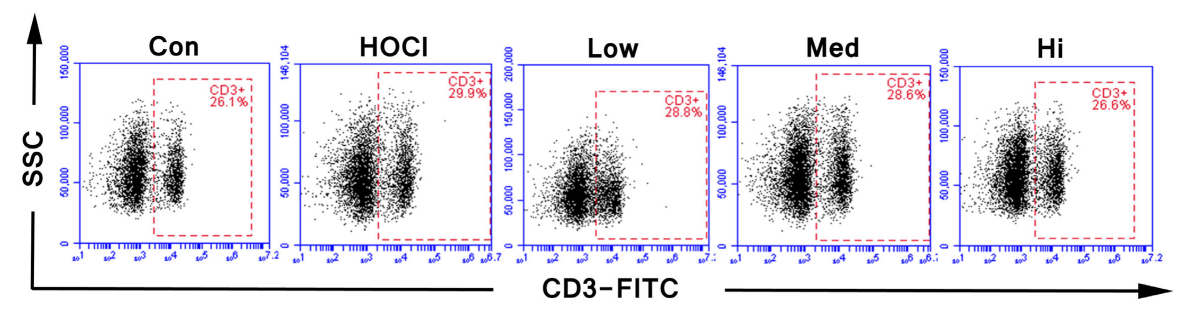

B

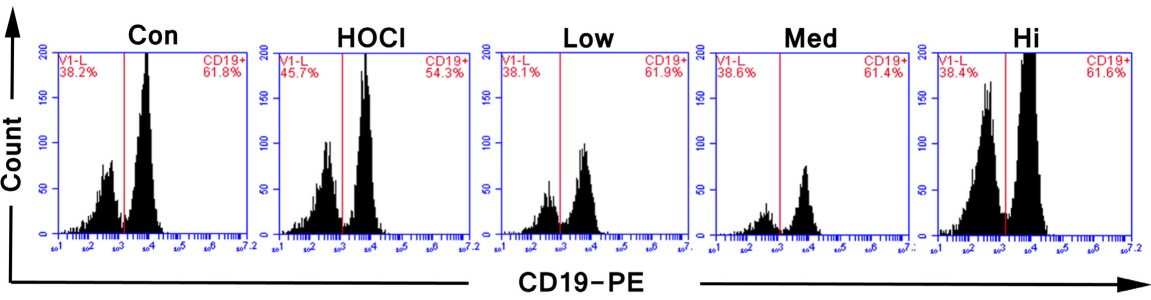

C

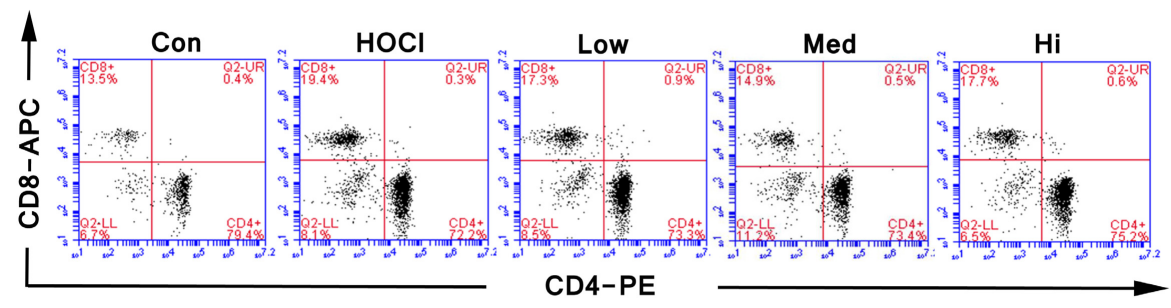

D

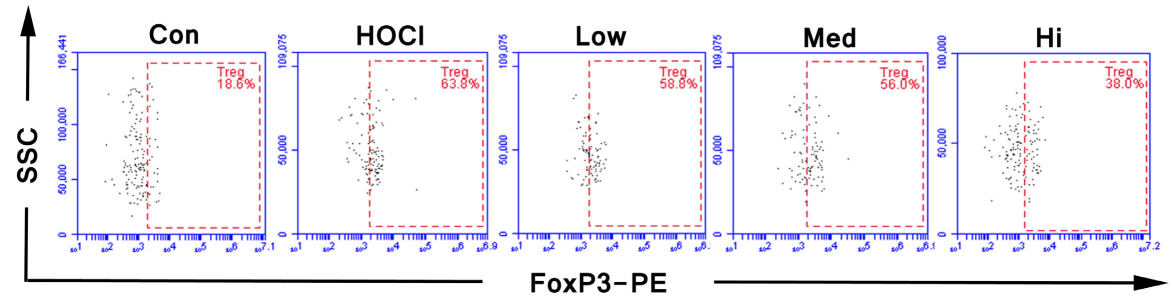

Fig. 7. The representative FACS cytograms of vivo experiment. The proportion of (A) $\mathrm{CD}^{+} \mathrm{T}^{+}$cells, (B) $\mathrm{CD} 19^{+}$B cells, (C) $\mathrm{CD}^{+} \mathrm{CD}^{+}$ helper $\mathrm{T}$ cells and $\mathrm{CD}^{+}{ }^{+} \mathrm{CD} 8^{+}$killing $\mathrm{T}$ cells, (D) $\mathrm{CD} 3^{+} \mathrm{CD} 4^{+} \mathrm{CD} 25^{+}$ FoxP $3^{+}$Treg cells in splenocytes of SSc mice treated with different doses of UC-MSCs. riod, the efficacy of human UC-MSC was stable. The continuous $\mathrm{HOCl}$ injection did not affect the strong protective effect of UC-MSC. Human UC-MSC has a longer term of effect compared to the mouse BM-MSC. In the future, the time of efficacy maintenance will be further explored.

In SSc, the mononuclear cell count is often increased or is activated, such as T lymphocyte, macrophage and mastocyte. In addition, eosinophil and endothelial cell are also activated (20-23). In addition, as main type of cell for acquired immune response, $\mathrm{B}$ cell produces excessive autoantibodies and immune complexes to cause an organ injury (24). In this study, the proportion or the count of B cells were not changed, and the change of its function should be further studied. Under the stimulation of PHA in vitro, or in the mouse model induced by $\mathrm{HOCl}$, the proportion of $\mathrm{CD}^{+}{ }^{+} \mathrm{T}$ cells was decreased but the proportion of $\mathrm{CD} 8^{+} \mathrm{T}$ cells was increased, and such abnormal change in the proportion of T cells could be regulated by MSCs, which was same as the conclusion of several relevant liter- atures (25-27). In the studies on SSc, whether Treg content was increased or not was still controversial. Some literatures reported that the number or proportion of Treg in patients with SSc was increased (28), while others reported that the proportion of Treg in patients with SSc remained unchanged or decreased (29). This may be related to the course of disease, severity, disease subtypes, history of drug treatment, etc., as well as the cell surface markers used in Treg detection. In recent years, the literatures have shown that Treg cells can be divided into many subgroups, and their immunomodulatory effects are different. Some subsets have inhibitory function, some subsets are in a resting state, and some subsets even have the ability to transform into Th17 cell $(30,31)$. Due to the pathogenesis of scleroderma, content and function of Treg cells are decreased at early inflammatory stage of disease. With the progression of disease, numerous immune cells are activated to secrete various cell factors (such as IL-1, IL-13, IL-7 and TGF- $\beta$ ). As an important inducing factor of Treg cell proliferation and differentiation, TGF- $\beta$ often 
leads to the increase of Treg cell content. Radstake et al. study (32) showed that $\mathrm{CD} 4{ }^{+} \mathrm{CD} 25^{+}$cells and $\mathrm{CD} 25^{+}$ $\mathrm{FoxP}^{+} \mathrm{CD}^{+} 27^{-}$cells in SSc patients were higher than control group, but their immunosuppressive ability was decreased. The results of Slobodin et al. (33) study also showed that Treg level was increased in patients with SSc, which was correlated with the activity and severity of the disease. These experimental data showed that the abnormality of Treg in peripheral blood of patients with SSc was not only abnormal in quantity, but also abnormal in quality. The immunosuppressive function of Treg cells in SSc was deficient. As we have found in our research, $\mathrm{CD} 4^{+}$ $\mathrm{CD} 25^{+} \mathrm{FoxP}^{+}$Treg cells did increase significantly in SSc mice. More importantly, our study explored for the first time that $\mathrm{HOCl}$-induced SSc mice model treated with UC-MSCs could improve the imbalance of $\mathrm{CD} 4{ }^{+} \mathrm{CD} 25^{+}$ FoxP3 $^{+}$Treg cells. The count and proportion of $\mathrm{CD}^{+}$ $\mathrm{CD} 4{ }^{+} \mathrm{CD} 25^{+} \mathrm{FoxP}^{+}$Treg cells were increased in SSc mice, but decreased after the MSCs treatment. The function of MSC should be further verified.

MSCs could play an immunosuppressive effect by directly contacting the immune cells and secreting various soluble cell factors. This study demonstrated that MSCs significantly inhibited the proliferation of $\mathrm{T}$ cells under PHA stimulation, and regulated the imbalance in proportion of $\mathrm{CD}^{+} / \mathrm{CD}^{+} \mathrm{T}$ cell, which was same as those reported in relevant literatures. On one hand, MSCs inhibit the mitogen-induced activation of T cells; one the other hand, MSCs make T cells stop at G0/G1 stage by inhibiting the expression of cyclin D2 to inhibit the proliferation and differentiation of T cells $(34,35)$. More importantly, MSCs release various soluble cell factors and chemotactic factors through the paracrine secretion (36), such as HGF, IL-4, IL1-RA, PGE2, IL-10, IDO/iNOS and TSG-6. The cell factors regulate the balance of $\mathrm{CD}^{+} /$ $\mathrm{CD}^{+} \mathrm{T}$ cell, Th1/Th2 cell and Th17/Treg cell through different routes and inhibit the autoantibody and immune cell infiltration, so as to regulate the autoimmune function of SSc patients and play the anti-inflammatory effect (37, 38). Furthermore, the lesions of arterioles and microvascular system caused by vascular endothelial damage and dysfunction are considered to be one of the initial factors in the pathogenesis of SSc. MSCs can release cytokines such as VEGF, IGF-1, HGF and PDGF through secretion, promote the differentiation of smooth muscle cells or pericytes, maintain the stability and integrity of blood vessels, thus promote angiogenesis, improve the Raynaud's phenomena, digital ulcer and other related symptoms caused by vascular injury in patients with SSc $(39,40)$. MSCs also release various regulatory factors for anti-fib- rosis (such as MMP2, MMP9, TIMP1, HGF, miR-199-3p and miR-151-5p), which improve the fibrosis symptoms of SSc patients in various organs such as skin, lung and digestive tract (8).

Our study revealed the preventive effect of human UC-MSCs on HOCl-induced SSc mice. UC-MSCs could significantly reduce skin thickening and alveolar wall thickening in SSc mice, improve skin and lung fibrosis and collagen deposition, and improve the balance of immune cells. Compared to the MSCs derived from other tissues, UC-MSCs have the advantages of secreting larger number of paracrine cytokines (41) and having stronger immunomodulatory ability (40). And compared to the effect of MSCs derived from patient autologous tissues, the UC-MSCs derived from allogeneic healthy people are better in function (19). UC-MSC could achieve an excellent preventive effect by a single injection. And it showed obvious curative effect earlier, and the effect can maintained for a long time. Therefore, UC-MSC has unique clinical value in the treatment of SSc.

\section{Acknowledgments}

This study was supported by the Natural Science Foundation of Hunan Province (2019JJ50812) and the Fundamental Research Funds for the Central Universities of Central South University (2018zzts837 and 1053320184 275). The funders had no role in the study design; the collection, analysis and interpretation of data; or the preparation and submission of the manuscript.

\section{Potential Conflict of Interest}

The authors have no conflicting financial interest.

\section{References}

1. Wu C, Chen Z, Dardalhon V, Xiao S, Thalhamer T, Liao M, Madi A, Franca RF, Han T, Oukka M, Kuchroo V. The transcription factor musculin promotes the unidirectional development of peripheral Treg cells by suppressing the TH2 transcriptional program. Nat Immunol 2017;18:344353

2. Du YM, Zhuansun YX, Chen R, Lin L, Lin Y, Li JG. Mesenchymal stem cell exosomes promote immunosuppression of regulatory T cells in asthma. Exp Cell Res 2018; 363:114-120

3. Zhang Z, Huang S, Wu S, Qi J, Li W, Liu S, Cong Y, Chen H, Lu L, Shi S, Wang D, Chen W, Sun L. Clearance of apoptotic cells by mesenchymal stem cells contributes to immunosuppression via PGE2. EBioMedicine 2019;45:341350

4. Kim JY, Park M, Kim YH, Ryu KH, Lee KH, Cho KA, Woo SY. Tonsil-derived mesenchymal stem cells (T-MSCs) 
prevent Th17-mediated autoimmune response via regulation of the programmed death-1/programmed death ligand-1 (PD-1/PD-L1) pathway. J Tissue Eng Regen Med 2018;12:e1022-e1033

5. Barnhoorn MC, Wasser MNJM, Roelofs H, Maljaars PWJ, Molendijk I, Bonsing BA, Oosten LEM, Dijkstra G, van der Woude CJ, Roelen DL, Zwaginga JJ, Verspaget HW, Fibbe WE, Hommes DW, Peeters KCMJ, van der Meulen-de Jong AE. Long-term evaluation of allogeneic bone marrow-derived mesenchymal stromal cell therapy for Crohn's disease perianal fistulas. J Crohns Colitis 2020;14:64-70

6. Martínez-Carrasco R, Sánchez-Abarca LI, Nieto-Gómez C, Martín García E, Sánchez-Guijo F, Argüeso P, Aijón J, Hernández-Galilea E, Velasco A. Subconjunctival injection of mesenchymal stromal cells protects the cornea in an experimental model of GVHD. Ocul Surf 2019;17:285-294

7. Rozier P, Maria A, Goulabchand R, Jorgensen C, Guilpain P, Noël D. Mesenchymal stem cells in systemic sclerosis: allogenic or autologous approaches for therapeutic use? Front Immunol 2018;9:2938

8. van den Hombergh WM, Carreira PE, Knaapen-Hans HK, van den Hoogen FH, Fransen J, Vonk MC. An easy prediction rule for diffuse cutaneous systemic sclerosis using only the timing and type of first symptoms and auto-antibodies: derivation and validation. Rheumatology (Oxford) 2016;55:2023-2032

9. Christopeit M, Schendel M, Föll J, Müller LP, Keysser G, Behre G. Marked improvement of severe progressive systemic sclerosis after transplantation of mesenchymal stem cells from an allogeneic haploidentical-related donor mediated by ligation of CD137L. Leukemia 2008;22:1062-1064

10. Keyszer G, Christopeit M, Fick S, Schendel M, Taute BM, Behre G, Müller LP, Schmoll HJ. Treatment of severe progressive systemic sclerosis with transplantation of mesenchymal stromal cells from allogeneic related donors: report of five cases. Arthritis Rheum 2011;63:2540-2542

11. Akiyama K, Chen C, Wang D, Xu X, Qu C, Yamaza T, Cai T, Chen W, Sun L, Shi S. Mesenchymal-stem-cell-induced immunoregulation involves FAS-ligand-/FAS-mediated T cell apoptosis. Cell Stem Cell 2012;10:544-555

12. Granel B, Daumas A, Jouve E, Harlé JR, Nguyen PS, Chabannon C, Colavolpe N, Reynier JC, Truillet R, Mallet S, Baiada A, Casanova D, Giraudo L, Arnaud L, Veran J, Sabatier F, Magalon G. Safety, tolerability and potential efficacy of injection of autologous adipose-derived stromal vascular fraction in the fingers of patients with systemic sclerosis: an open-label phase I trial. Ann Rheum Dis 2015;74:2175-2182

13. Van Pham P, Truong NC, Le PT, Tran TD, Vu NB, Bui $\mathrm{KH}$, Phan NK. Isolation and proliferation of umbilical cord tissue derived mesenchymal stem cells for clinical applications. Cell Tissue Bank 2016;17:289-302

14. Maria ATJ, Rozier P, Fonteneau G, Sutra T, Maumus M, Toupet K, Cristol JP, Jorgensen C, Guilpain P, Noël D. iNOS activity is required for the therapeutic effect of mesenchymal stem cells in experimental systemic sclerosis.
Front Immunol 2018;9:3056

15. Hughes $M$, Ong VH, Anderson ME, Hall F, Moinzadeh P, Griffiths B, Baildam E, Denton CP, Herrick AL. Consensus best practice pathway of the UK Scleroderma Study Group: digital vasculopathy in systemic sclerosis. Rheumatology (Oxford) 2015;54:2015-2024

16. Cavagna L, Codullo V, Ghio S, Scirè CA, Guzzafame E, Scelsi L, Rossi S, Montecucco C, Caporali R. Undiagnosed connective tissue diseases: high prevalence in pulmonary arterial hypertension patients. Medicine (Baltimore) 2016; 95:e4827

17. Giacomelli R, Liakouli V, Berardicurti O, Ruscitti P, Di Benedetto P, Carubbi F, Guggino G, Di Bartolomeo S, Ciccia F, Triolo G, Cipriani P. nterstitial lung disease in systemic sclerosis: current and future treatment. Rheumatol Int 2017;37:853-863

18. Capelli C, Zaccara E, Cipriani P, Di Benedetto P, Maglione W, Andracco R, Di Luca G, Pignataro F, Giacomelli R, Introna $M$, Vitali C, Del Papa N. Phenotypical and functional characteristics of in vitro-expanded adipose-derived mesenchymal stromal cells from patients with systematic sclerosis. Cell Transplant 201726:841-854

19. Griffin M, Ryan CM, Pathan O, Abraham D, Denton CP, Butler PE. Characteristics of human adipose derived stem cells in scleroderma in comparison to sex and age matched normal controls: implications for regenerative medicine. Stem Cell Res Ther 2017;8:23

20. Soldano S, Trombetta AC, Contini P, Tomatis V, Ruaro B, Brizzolara R, Montagna P, Sulli A, Paolino S, Pizzorni C, Smith V, Cutolo $M$. Increase in circulating cells coexpressing $\mathrm{M} 1$ and $\mathrm{M} 2$ macrophage surface markers in patients with systemic sclerosis. Ann Rheum Dis 2018;77:1842-1845

21. Taniguchi T, Asano Y, Akamata K, Noda S, Takahashi T, Ichimura Y, Toyama T, Trojanowska M, Sato S. Fibrosis, vascular activation, and immune abnormalities resembling systemic sclerosis in bleomycin-treated Fli-1-haploinsufficient mice. Arthritis Rheumatol 2015;67:517-526

22. Wuttge DM, Andreasson A, Tufvesson E, Johansson ÅC, Scheja A, Hellmark T, Hesselstrand R, Truedsson L. CD81 and CD48 show different expression on blood eosinophils in systemic sclerosis: new markers for disease and pulmonary inflammation? Scand J Rheumatol 2016;45:107-113

23. Manetti M, Romano E, Rosa I, Guiducci S, BellandoRandone S, De Paulis A, Ibba-Manneschi L, MatucciCerinic M. Endothelial-to-mesenchymal transition contributes to endothelial dysfunction and dermal fibrosis in systemic sclerosis. Ann Rheum Dis 2017;76:924-934

24. Koenig M, Bentow C, Satoh M, Fritzler MJ, Senécal JL, Mahler M. Autoantibodies to a novel Rpp38 (Th/To) derived B-cell epitope are specific for systemic sclerosis and associate with a distinct clinical phenotype. Rheumatology (Oxford) 2019;58:1784-1793

25. Shu J, Pan L, Huang X, Wang P, Li H, He X, Cai Z. Transplantation of human amnion mesenchymal cells attenuates the disease development in rats with collagen-induced arthritis. Clin Exp Rheumatol 2015;33:484-490 
26. Thiel A, Yavanian G, Nastke MD, Morales P, Kouris NA, Kimbrel EA, Lanza R. Human embryonic stem cell-derived mesenchymal cells preserve kidney function and extend lifespan in NZB/W F1 mouse model of lupus nephritis. Sci Rep 2015;5:17685

27. Li H, Guo ZK, Li XS, Hou CM, Tang PH, Mao N. Functional and phenotypic alteration of intrasplenic lymphocytes affected by mesenchymal stem cells in a murine allosplenocyte transfusion model. Cell Transplant 2007;16: 85-95

28. Ugor E, Simon D, Almanzar G, Pap R, Najbauer J, Németh P, Balogh P, Prelog M, Czirják L, Berki T. Increased proportions of functionally impaired regulatory $\mathrm{T}$ cell subsets in systemic sclerosis. Clin Immunol 2017;184:54-62

29. Negrini S, Fenoglio D, Parodi A, Kalli F, Battaglia F, Nasi G, Curto M, Tardito S, Ferrera F, Filaci G. Phenotypic alterations involved in CD8 + Treg impairment in systemic sclerosis. Front Immunol 2017;8:18

30. Rosenbaum M, Gewies A, Pechloff K, Heuser C, Engleitner T, Gehring T, Hartjes L, Krebs S, Krappmann D, Kriegsmann M, Weichert W, Rad R, Kurts C, Ruland J. Bcll0-controlled Maltl paracaspase activity is key for the immune suppressive function of regulatory $\mathrm{T}$ cells. Nat Commun 2019;10:2352

31. Pathak S, Regmi S, Shrestha P, Choi I, Doh KO, Jeong JH. Mesenchymal stem cell capping on ECM-anchored caspase inhibitor-loaded PLGA microspheres for intraperitoneal injection in DSS-induced murine colitis. Small 2019;15: e1901269

32. Radstake TR, van Bon L, Broen J, Wenink M, Santegoets K, Deng Y, Hussaini A, Simms R, Cruikshank WW, Lafyatis R. Increased frequency and compromised function of $\mathrm{T}$ regulatory cells in systemic sclerosis (SSc) is related to a diminished CD69 and TGFbeta expression. PLoS One 2009;4:e5981

33. Slobodin G, Ahmad MS, Rosner I, Peri R, Rozenbaum M, Kessel A, Toubi E, Odeh M. Regulatory T cells (CD4+
CD25brightFoxP3 +) expansion in systemic sclerosis correlates with disease activity and severity. Cell Immunol 2010; 261:77-80

34. Groh ME, Maitra B, Szekely E, Koç ON. Human mesenchymal stem cells require monocyte-mediated activation to suppress alloreactive T cells. Exp Hematol 2005;33:928-934

35. Glennie S, Soeiro I, Dyson PJ, Lam EW, Dazzi F. Bone marrow mesenchymal stem cells induce division arrest anergy of activated T cells. Blood 2005;105:2821-2827

36. Aggarwal S, Pittenger MF. Human mesenchymal stem cells modulate allogeneic immune cell responses. Blood 2005; 105:1815-1822

37. Maria AT, Maumus M, Le Quellec A, Jorgensen C, Noël D, Guilpain P. Adipose-derived mesenchymal stem cells in autoimmune disorders: state of the art and perspectives for systemic sclerosis. Clin Rev Allergy Immunol 2017;52:234259

38. Cras A, Farge D, Carmoi T, Lataillade JJ, Wang DD, Sun L. Update on mesenchymal stem cell-based therapy in lupus and scleroderma. Arthritis Res Ther 2015;17:301

39. Cutolo M, Ruaro B, Montagna P, Brizzolara R, Stratta E, Trombetta AC, Scabini S, Tavilla PP, Parodi A, Corallo C, Giordano N, Paolino S, Pizzorni C, Sulli A, Smith V, Soldano S. Effects of selexipag and its active metabolite in contrasting the profibrotic myofibroblast activity in cultured scleroderma skin fibroblasts. Arthritis Res Ther 2018;20:77

40. Tan K, Zheng K, Li D, Lu H, Wang S, Sun X. Impact of adipose tissue or umbilical cord derived mesenchymal stem cells on the immunogenicity of human cord blood derived endothelial progenitor cells. PLoS One 2017;12:e0178624

41. Miranda JP, Camões SP, Gaspar MM, Rodrigues JS, Carvalheiro M, Bárcia RN, Cruz P, Cruz H, Simões S, Santos JM. The secretome derived from 3D-cultured umbilical cord tissue MSCs counteracts manifestations typifying rheumatoid arthritis. Front Immunol 2019;10:18 